\title{
Cetacean movements in coastal waters of the southwestern Atlantic ocean
}

\author{
Marcos C. de O. Santos ${ }^{1 *}{ }^{\mathbb{D}}$, José Laílson-Brito ${ }^{2}$,Leonardo Flach ${ }^{3}$, Júlia E. F. Oshima ${ }^{4}$, Giovanna C. Figueiredo ${ }^{1}$,
}

Rafael R. Carvalho', Elisa S. Ventura ${ }^{1}$, Julia M. B. Molina ${ }^{1}$ \& Alexandre F. Azevedo ${ }^{2}$

${ }^{1}$ Universidade de São Paulo, Departamento de Oceanografia Biológica, Instituto Oceanográfico, Laboratório de Biologia da Conservação de Mamíferos Aquáticos, Praça do Oceanográfico, 191, Butantã, 05508-120, São Paulo, SP, Brasil

${ }^{2}$ Universidade do Estado do Rio de Janeiro, Faculdade de Oceanografia, Laboratório de Mamíferos Aquáticos de Bioindicadores "Professora Izabel Gurgel”, Rua São Francisco Xavier, 524, Maracanã, 20550-013, Rio de Janeiro, RJ, Brasil

${ }^{3}$ Instituto Boto-Cinza, Rua Gastão de Carvalho, Itacuruçá, 23860-000, Rio de Janeiro, RJ, Brasil ${ }^{4}$ Universidade Estadual Paulista, Programa de Pós-graduação em Zoologia, Instituto de Biociências, Laboratório de Ecologia Espacial e Conservação, Campus Rio Claro, Avenida 24-A, 1515, Bela Vista, 13506-900, Rio Claro, SP, Brasil *Corresponding author: Marcos C. de O. Santos, e-mail: sotalia@gmail.com

SANTOS, M.C.O., LAIILSON-BRITO, J., FLACH, L., OSHIMA, J.E.F., FIGUEIREDO, G.C., CARVALHO, R.R., VENTURA, E.S., MOLINA, J.M.B., AZEVEDO, A.F. Cetacean Movements in Coastal Waters of the Southwestern Atlantic Ocean. Biota Neotropica. 19(2): e20180670. http://dx.doi.org/10.1590/1676-0611BN-2018-0670

\begin{abstract}
Cetaceans were monitored along $\mathrm{ca} .700 \mathrm{~km}$ of the southeast coast of Brazil ( $22^{\circ} \mathrm{S}$ to $25^{\circ} \mathrm{S}$ ) from 1995 to $2014 \mathrm{using}$ photo-identification. The objective of this study was to identify any presence of long-distance movements for monitored cetacean species and discuss implications. Data on long-range movements of four of the monitored species are presented after the analysis of 321,765 photographs taken for individual identification. Seven individuals from four populations of Guiana dolphins (Sotalia guianensis) considered resident to particular estuaries or bays were reported in dispersal involving movement between pairs of protected areas over long-range distances varying between 86 and $135 \mathrm{~km}$. Three cataloged rough-toothed dolphins (Steno

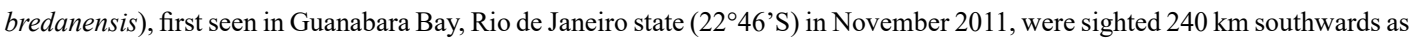

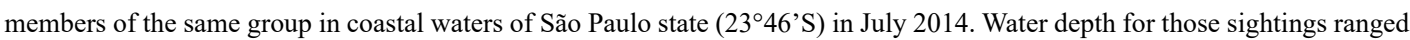
from 16 to $52.7 \mathrm{~m}$; local sightings of rough-toothed dolphins in Brazil have frequently been in shallow waters, but the species global distribution is usually associated with deeper waters. In a 27-day interval in the spring of 2012, a group of 16 orcas (Orcinus orca) travelled $c a .277 \mathrm{~km}$ in shallow coastal waters ranging from 20 to $30 \mathrm{~m}$ deep. Orcas are commonly observed between November and February in southeast Brazil, probably in search for prey. In summer months between 2012 and 2014, three Bryde's whales (Balaenoptera edeni) sighted in waters ranging from 14 to $49 \mathrm{~m}$ deep, moved between 218 and $327 \mathrm{~km}$. Bryde's whales are usually found in local coastal waters where they spend summer months feeding on sardines. To date, these are the longest estimated movements reported to S. guianensis, S. bredanensis, O. orca and B. edeni in the Southwestern Atlantic Ocean. Keywords: Movements; Sotalia guianensis; Steno bredanensis; Orcinus orca; Balaenoptera edeni.
\end{abstract}

\section{Movimentos de cetáceos pelas águas costeiras do sudoeste do oceano Atlântico}

Resumo: Cetáceos foram monitorados em cerca de $700 \mathrm{~km}$ da costa sudeste do Brasil ( $22^{\circ} \mathrm{S}$ a $\left.25^{\circ} \mathrm{S}\right)$ entre 1995 e 2014 com o uso da fotoidentificação. O objetivo deste estudo foi de identificar quaisquer presenças de movimentos de longa distância de indivíduos das espécies monitoradas e discutir suas implicações. Dados de movimentos de longa distância de quatro das espécies monitoradas são apresentados após a análise de 321.765 fotos obtidas para identificações individuais. Sete indivíduos de quatro populações de boto-cinza (Sotalia guianensis) consideradas residentes a estuários e baías particulares foram reportados em movimentos de dispersão envolvendo pares de áreas protegidas em distâncias que variaram entre 86 e 135 km. Três golfinhos-de-dentes-rugosos (Steno bredanensis) catalogados e avistados primeiramente na Baía de Guanabara, Rio de Janeiro (2246’S), em novembro de 2011,

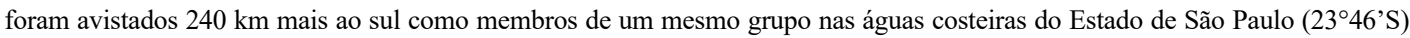
em julho de 2014. A profundidade da água onde essas avistagens aconteceram variou entre 16 e 52,7 m; avistagens de golfinhosde-dentes-rugosos têm sido efetuadas em águas rasas na costa sudeste do Brasil, embora a distribuição global da espécie esteja associada a águas profundas. Em um intervalo de 27 dias na primavera de 2012, um grupo de 16 orcas (Orcinus orca) se desclocou cerca de $277 \mathrm{~km}$ em águas rasas variando entre 20 e $30 \mathrm{~m}$. Orcas são comumente avistadas entre novembro e fevereiro no sudeste do Brasil, possivelmente em busca de presas. Nos meses de verão entre 2012 e 2014, três baleias-de-Bryde (Balaenoptera edeni) avistadas em águas de 14 a 49 m de profundidade, moveram-se entre 218 e 327 km. baleias-de-Bryde são encontradas em águas costeiras locais onde passam os meses de verão se alimentando de sardinhas. Até o presente momento, esses são os deslocamentos estimados como os de maiores distâncias observados para S. guianensis, S. bredanensis, O. orca and B. edeni no Atlântico Sudoeste. Palavras-chave: Movimentos; Sotalia guianensis; Steno bredanensis; Orcinus orca; Balaenoptera edeni. 


\section{Introduction}

Movement is a hallmark of marine mammal behavior and an important component to understanding how they use their world (Stern 2009). Movements play pivotal roles in shaping biodiversity across spatiotemporal scales, determining patterns in species distribution and interactions, changing genetic traits and diversity, and modifying habitat structures and resource levels (Jeltsch et al. 2013). It is thus not a coincidence that "movement ecology" turned into a new ecological discipline, rapidly expanding worldwide (see Nathan et al. 2008).

As of October 2018, 47 cetacean species were reported in Brazilian aquatic environments (Santos et al. 2010a, Cypriano-Souza et al. 2017), which represents $c a .50 \%$ of all described species worldwide (see Committee on Taxonomy 2017). Among cetacean species found in the Southwestern Atlantic Ocean (SAO), four are of interest in this study due to the lack of prior focus on their long-range movements in this region: the Guiana dolphin - Sotalia guianensis (Van Bénéden 1864), Bryde's whale - Balaenoptera edeni Anderson 1879, orca - Orcinus orca (Linnaeus 1758), and rough-toothed dolphin - Steno bredanensis (G. Cuvier in Lesson 1828). The most common cetacean species found within Brazilian waters is the Guiana dolphin, dwelling in shallow coastal and estuarine waters; Brazilian occurrences extends from the country's northern border shared with French Guiana down the coast to the southern limit of the species distribution, in the state of Santa Catarina in southern Brazil (Da Silva et al. 2010).

Bryde's whales are usually found in coastal waters of southeast Brazil, where they spend mainly spring and summer months feeding on sardines (Siciliano et al. 2004). Stranding events of adults and juveniles are reported year-round in this region without a marked seasonality (Moura \& Siciliano 2012). Bryde's whales are amongst the least known of the larger baleen whales and are commonly found in tropical and subtropical waters worldwide (Kato \& Perrin 2009). Along the northeast coast of Brazil, a few sightings and catches in whaling operations with possible misidentifications with sei (B. borealis) and Omura's whales (B. omurai) were reported in the past decades (Andriolo et al. 2010). Little is known about movements and migration patterns of all stocks.

Orcas are cosmopolitan cetaceans found in all oceans, most commonly observed in coastal and temperate waters, especially in areas of high productivity (Heyning \& Dahlheim 1988, Ford 2009). They are known to display both short and long-scale movements, the latter reaching $c a .5,400 \mathrm{~km}$ to cope with biological and ecological requirements such as finding food patches, adapting to a seasonally changing environment, and investing in interactions with other social units (Dahlheim et al. 2008, Matthews et al. 2011, Fearnbach et al. 2014). Migration was recently attributed to orcas in the southern hemisphere, possibly evidence of coping with physiological requirements (Durban \& Pitman 2012). Sightings have been occasionally observed along the Brazilian coast, with a higher number of records in southeastern waters between November and February (Siciliano et al. 1999). Unpublished aerial images have been showing orcas preying on rays in local shallow waters. However, no information is available on their local abundance, movements and distribution.

While rough-toothed dolphins are widely distributed throughout tropical and warm-temperate waters worldwide, little is known about this species anywhere in their range (Baird et al., 2008). Their global distribution is usually associated to deeper waters, but they have been frequently sighted in shallow waters in southeast Brazil (Lodi 1992, Lodi \& Hetzel 1999, West et al. 2011). The only known information on rough-toothed dolphin movements in the SAO was reported by Lodi et al. (2012). Those authors witnessed the movement of four cataloged individuals along the coast of Rio de Janeiro, reaching up to $119.7 \mathrm{~km}$ in a short window of time between August and September 2011.

A large proportion of what is known about cetaceans in Brazilian waters comes from studies using dead individuals collected from stranding events (e.g. Zerbini et al. 1997, Greig et al. 2001; Ramos et al. 2001, Costa et al. 2017) and/or incidental catches in fishing operations conducted since the end of the 1970s (e.g. Siciliano 1994). Starting only at the end of the 1980s, live cetaceans are now also being studied in their element along the $c a .8,500 \mathrm{~km}$ shoreline. Based on their distribution and close proximity to scientific institutions, longterm studies have been conducted on resident bottlenose dolphin populations in southern Brazil (e.g. Simões-Lopes \& Fabián 1999, Fruet et al. 2011; 2015) and resident Guiana dolphin populations in southern and southeastern Brazil (e.g. Flores 1999, Santos et al. 2000, Azevedo et al. 2004).

For the most part, these studies focused on several aspects of behavioral observations, then most used the technique of photoidentification to follow individuals on a relatively restricted spatial and temporal scale. Throughout its range, investigations on area utilization by $S$. guianensis was based on photo-identification and showed that surveyed populations are resident to the investigated sites (see Flores 1999, Santos et al. 2001, Azevedo et al. 2007), with travel distances reaching up to $30 \mathrm{~km}$, and home ranges averaging between 13.5 to 72.4 $\mathrm{km}^{2}$ (Flores \& Bazzalo, 2004, Oshima \& Santos 2016). Most studies on $S$. guianensis have been conducted in protected bays and estuaries, a different scenario when compared to cetacean species found in open waters. Open water investigations have recently been providing the first insights on the occurrence, movements and relation to physical ocean conditions for several other cetaceans (see Di Tullio et al. 2016), but insignificant in scope when compared to the larger body of work devoted to $S$. guianensis and T. truncatus in bays and estuaries. As a consequence, information on individual movements out of the home ranges of considered resident populations is still scarce over an extensive area of the (SAO), where more than half of the global cetacean species had already been reported.

Photo-identification is the most economically accessible technique in developing regions across the globe to gather important information regarding cetacean ecology, but until now has not been used comprehensively to understand long-range movements. In recent years, satellite tags have been used as one of the main tools to analyze movements of long-ranging aquatic species such as cetaceans (see Hussey et al. 2015), but such techniques would be limited to a small pool of individuals due to economic and import restrictions. Sampling a considerable number of individuals of different gender, age and personality is essential to avoid bias when describing population traits. Improvements in photo quality in recent years have made image analysis more robust due to the higher density of pixels available to identify features (Urian et al. 2015). This study thus provides new information on long-range movements of four cetacean species ( $S$. guianensis, $B$. edeni, O. orca and S. bredanensis) along the southeast coast of Brazil using photo-identification to follow cataloged individuals. 


\section{Materials and Methods}

Data were collected in different studies conducted from 1995 to 2014 dedicated to investigating cetacean ecology using photo-identification in estuaries, bays and coastal waters of southeast Brazil (Fig. 1), all based on onboard observations.

Four studies were undertaken in four protected bays and estuaries to investigate population parameters and aspects of ecology of Guiana dolphins (Sotalia guianensis). The Lagamar Estuary is composed of the Paranaguá Estuarine Complex (PEC), $3,870 \mathrm{~km}^{2}$ on the northern coast of Paraná state (Noernberg et al. 2006), and the Cananéia Estuary (CE), a $234 \mathrm{~km}^{2}$ area on the southern tip of São Paulo state (SMA, 1991). Both areas are connected through a $5 \mathrm{~km}$ long man-made channel dug in the 1950s. Investigations in the CE took place from 2000 to 2010 in 132 $\mathrm{km}^{2}$ of inner estuarine waters used by Guiana dolphins (see details in Oshima et al. 2010, Oshima \& Santos 2016). In the PEC, investigations on Guiana dolphins were conducted between 2006 and 2009 in $124 \mathrm{~km}^{2}$ of protected estuarine waters (see Santos et al. 2010b). The Sepetiba Bay (SPB), on the coast of Rio de Janeiro state, is $526 \mathrm{~km}^{2}$, with $c a .425$ $\mathrm{km}^{2}$ of that area surveyed for Guiana dolphins since 2005 (see Flach et al. 2008, Dias et al. 2009). Also along the coast of Rio de Janeiro, the $328 \mathrm{~km}^{2}$ Guanabara Bay (GB) (Kjerfve et al. 1997) and adjacent coastal waters have been surveyed for Guiana dolphins since 1995 (details in Azevedo et al. 2007).

Three investigations have been directed towards mapping the occurrence, movements and sound emissions of cetaceans along the shoreline of Paraná, São Paulo and Rio de Janeiro states. Since 2008, $\mathrm{GB}$ and adjacent coastal waters up to the $50 \mathrm{~m}$ isobath have been surveyed for a cetacean multi-species study to describe their distribution, movements and sound emissions. Moving southwards, the marine protected area known as Parque Estadual Marinho da Laje de Santos (PEMLS), on the São Paulo state coast, was the target of a two-year cetacean multi-species monitoring program conducted between May 2013 and June 2015 to map their occurrence (see Santos et al. 2017). From December 2012 to December 2014, ca. $650 \mathrm{~km}$ of coastal waters in a straight line along the states of São Paulo and Paraná was covered by another multi-species study of cetaceans. The area was surveyed using 6-day cruises screening a corridor of water depths ranging between $15 \mathrm{~m}$ and $40 \mathrm{~m}$. The aims were to map cetacean occurrence, movements and sound emissions. In Table 1, efforts and results gathered to multi-species surveys along the coast of São Paulo were merged, as they were conducted in the same area. These listed efforts were not evenly distributed in time and space.

Outboard-powered vessels with sizes ranging from 5 to $16 \mathrm{~m}$ were the mobile platforms used in all studies. All surveyed subsets of the monitored estuaries, bays and coastline had specific tracks to be followed to optimize the chances of encountering cetaceans. Cruises were undertaken in sea states up to 3 Beaufort on the wind scale. When cetaceans were found, the specific sighting location (GPS position), water depth, salinity and superficial temperature at most occasions were recorded. Afterwards, vessels approached cetaceans to estimate group size and invest in gathering photographs to identify individuals. Photographs of dorsal fins of all sighted cetaceans and flukes for humpback whales were taken using film (1995 to 2005) or digital SLR cameras with 300 to $400 \mathrm{~mm}$ zoom lenses. Printed photos of past catalogs were scanned. Catalogs were organized by each species to check for the addition of new identified individuals of the investigated populations/stocks and to confirm re-sightings of known and previously sighted individuals following procedures described by

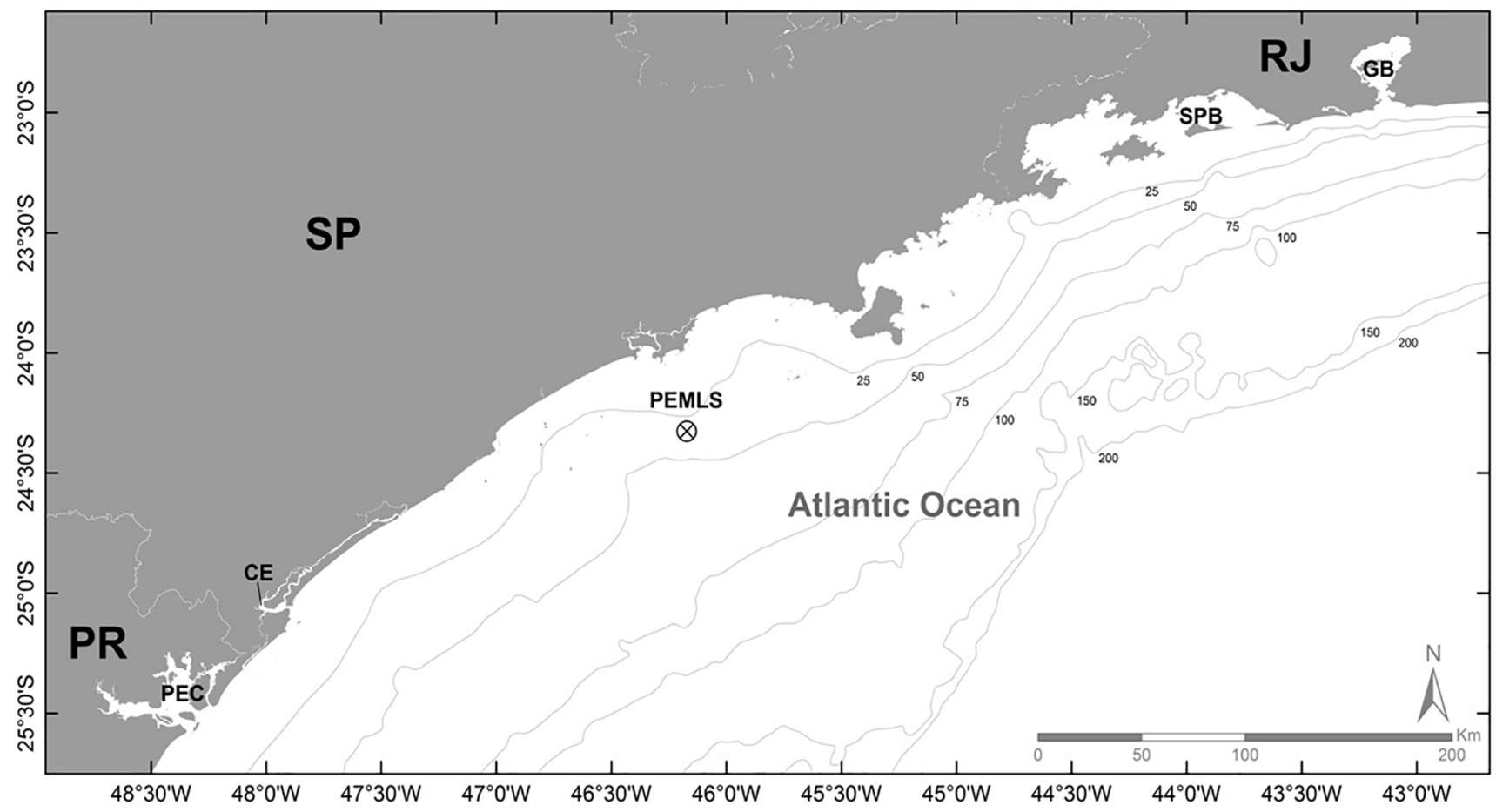

Figure 1. Map of the surveyed area used to investigate cetacean movements along the southeast coast of Brazil, covering part of Paraná (PR) state coast, São Paulo (SP) state coast, and Rio de Janeiro (RJ) state coast. The following subsets were the main targets of Guiana dolphin investigations: The Paranaguá Estuarine Complex (PEC) in PR state, the Cananéia Estuary (CE) in SP state, and the Sepetiba (SPB) and Guanabara (GB) Bays in RJ state. PEMLS means "Parque Estadual Marinho da Laje de Santos", a coastal Marine Protected Area. 
Table 1. Summarized efforts invested in the investigation of cetacean movements along the southeast coast of Brazil from 1995 to 2014 using photo-identification. Target species (SG means Sotalia guianensis; Multi means multi-species surveys), length of time of surveys in years, main surveyed regions, their estimated area, the number of photographs taken and analyzed, and the number of identified individuals are presented. Acronyms: $\mathrm{CE}=\mathrm{Cananeia}$ Estuary; $\mathrm{PEC}=\mathrm{Paranaguá}$ Estuarine Complex; SPB = Sepetiba Bay; GB = Guanabara Bay; SP = São Paulo; RJ = Rio de Janeiro.

\begin{tabular}{lccccc}
\hline Region & Species & Years & Area $\left(\mathbf{k m}^{\mathbf{2}}\right)$ & \# Photos & \# Ids \\
\hline CE & SG & $2000-2010$ & 132 & 85,925 & 49,921 \\
PEC & SG & $2006-2009$ & 124 & 130,000 \\
SPB & SG & $2005-2014$ & 425 & 12,154 & 188 \\
GB & SG & $1995-2014$ & 328 & 13,224 & 108 \\
Coast RJ & Multi & $2008-2014$ & 1,200 & 30,541 & 320 \\
Coast SP & Multi & $2012-2014$ & 11,000 & 333,919 \\
TOTAL & Multi & $1995-2014$ & 13,209 & 397 \\
\hline
\end{tabular}

Würsig \& Jefferson (1990). Photographs were analyzed and compared by at least two investigators using the Nikon View software and, more recently, Darwin (Stewman et al. 2006). Catalogs were compared among areas to find matches of identified individuals, the main evidence of movement between two different locations. Distances travelled by cetaceans were estimated using ArcGIS 9.1 (ESRI), linking distant locations involving a sighting and a re-sighting of the same individual. When bays and estuaries were included in the analysis, the estimate evaluated the shortest distance to connect the inner location to the further distant location in another protected area, leaving the protected site and travelling along the coast. For sightings reported exclusively in open shoreline waters, only the shortest connection between the two most distant locations was used to estimate the travelled distance.

\section{Results}

\section{Guiana dolphins, Sotalia guianensis}

Considering the surveyed bays and estuaries where Guiana dolphins were found, four catalogs were organized for PEC, CE, SPB, and GB. The number of identified individuals, showing the number of analyzed photographs in parenthesis, were: $\mathrm{PEC}=188(49,921), \mathrm{CE}=199$ $(85,925), \mathrm{SPB}=820(130,000)$, and GB $=108(12,154)($ see Table 1$)$. Overall, 1,315 Guiana dolphins were cataloged after the analysis of 278,000 dorsal fin photographs. Two individuals (KN 159 and 194) from the considered resident population of Guiana dolphins, sighted between 2000 and 2008 in CE inner waters, were reported for the first time in coastal waters in May 2005, ca. $10 \mathrm{~km}$ distant from the main estuarine entrance. This short-range movement is the first evidence of the plasticity in the use of coastal waters by Guiana dolphins monitored in local protected inner estuaries. Both individuals were female adults and had at least two calves in eight years, with several sightings in the same group, close to the main entrance of the $\mathrm{CE}$. In an interval ranging from one to seven years, another four individuals switched between the PEC and $\mathrm{CE}$ estuaries (Table 2, Figure 2). Their movements, considering the most distant locations in inner estuarine basins through coastal waters, ranged between 86 and $124 \mathrm{~km}$, the longest distances reported so far for the species in local waters. The first cataloged dolphin sighted once in the PEC (PR 001) in May 2002 was re-sighted in August 2009 in the $\mathrm{CE}$, where it was cataloged as KN 363. Two adult dolphins, sighted on one (KN 251) and four (KN 300) occasions at the main entrance of the CE in 2001, between 2005 and 2007, respectively, were seen in the same group in the PEC (PR 116 and 115) in October 2008. An adult female (KN 209), sighted on 10 different occasions all over the CE between 2000 and 2006, was seen in November 2008 in the PEC (PR 121). This dolphin had a calf in 2003, which was previously seen with its mother up to 2006 in the CE. The mother was again observed with another calf in 2008 in the PEC.

Three adult individuals (SEP 411, 481 and 783), sighted from one (SEP 783) to seven (SEP 481) distinct occasions in the SPB between March 2006 and January 2012, were photographed in the same group $135 \mathrm{~km}$ northwards in December 2012 at the main entrance of the GB, where they were assigned as BG 097, 096 and 098, respectively (Table 2, Figure 3). In previous sightings, SEP 411 and 481 shared the same group on at least three occasions, while SEP 783 was sighted only once in the SPB. These three Guiana dolphins have been sighted in the same group inside the GB. For $S$. guianensis, the estimated range of $135 \mathrm{~km}$ is so far the longest distance reported for an individual dolphin.

\section{Multi-species}

Along the coast of São Paulo state, eleven cetacean species (23\% of the total reported in Brazilian waters) were reported between December 2012 and December 2014 after 13 cruises. The analysis of 30,541 photographs resulted in 11 catalogs, with the number of identified individuals represented in parenthesis: Guiana dolphin, S. guianensis (2), common bottlenose dolphin, Tursiops truncatus (121), Atlantic spotted dolphin, Stenella frontalis (162), long-beaked common dolphin, Delphinus delphis (14), rough-toothed dolphin, Steno bredanensis (71), orca, Orcinus orca (6), La Plata dolphin, Pontoporia blainvillei (1), humpback whale, Megaptera novaeangliae (1), Bryde's whale, Balaenoptera edeni (6), dwarf minke whale, Balaenoptera acutorostrata (3), and Antarctic minke whale, B. bonaerensis (1). On the Rio de Janeiro state coast, the following species ( $\mathrm{n}=4 ; 8 \%$ of the total reported in Brazilian waters) were reported to have individually marked individuals: T. truncatus (21), S. bredanensis (139), O. orca (9), and B. edeni (12). These individuals were identified from the analysis of 13,224 photographs.

\section{Rough-toothed dolphins, Steno bredanensis}

Three cataloged rough-toothed dolphins (SBRJ 005, 025 and 030), first seen in coastal waters of Rio de Janeiro state in November 2009, were reported in the same group in December 2013 in areas closer to shore and $240 \mathrm{~km}$ southwards near the shoreline of São Paulo state (SB 027, 029 and 030) in July 2014 (Table 2, Figure 4). Water depth where these dolphins were observed ranged from 16 to $52.7 \mathrm{~m}$. 
Table 2. Matching of 15 cataloged individuals of 4 cetacean species monitored along the southeast coast of Brazil from 1995 to 2014. Catalog numbers are presented (ID), as well as date and locations of first and last sightings related to the longest travelled distances, which is shown in the last column.

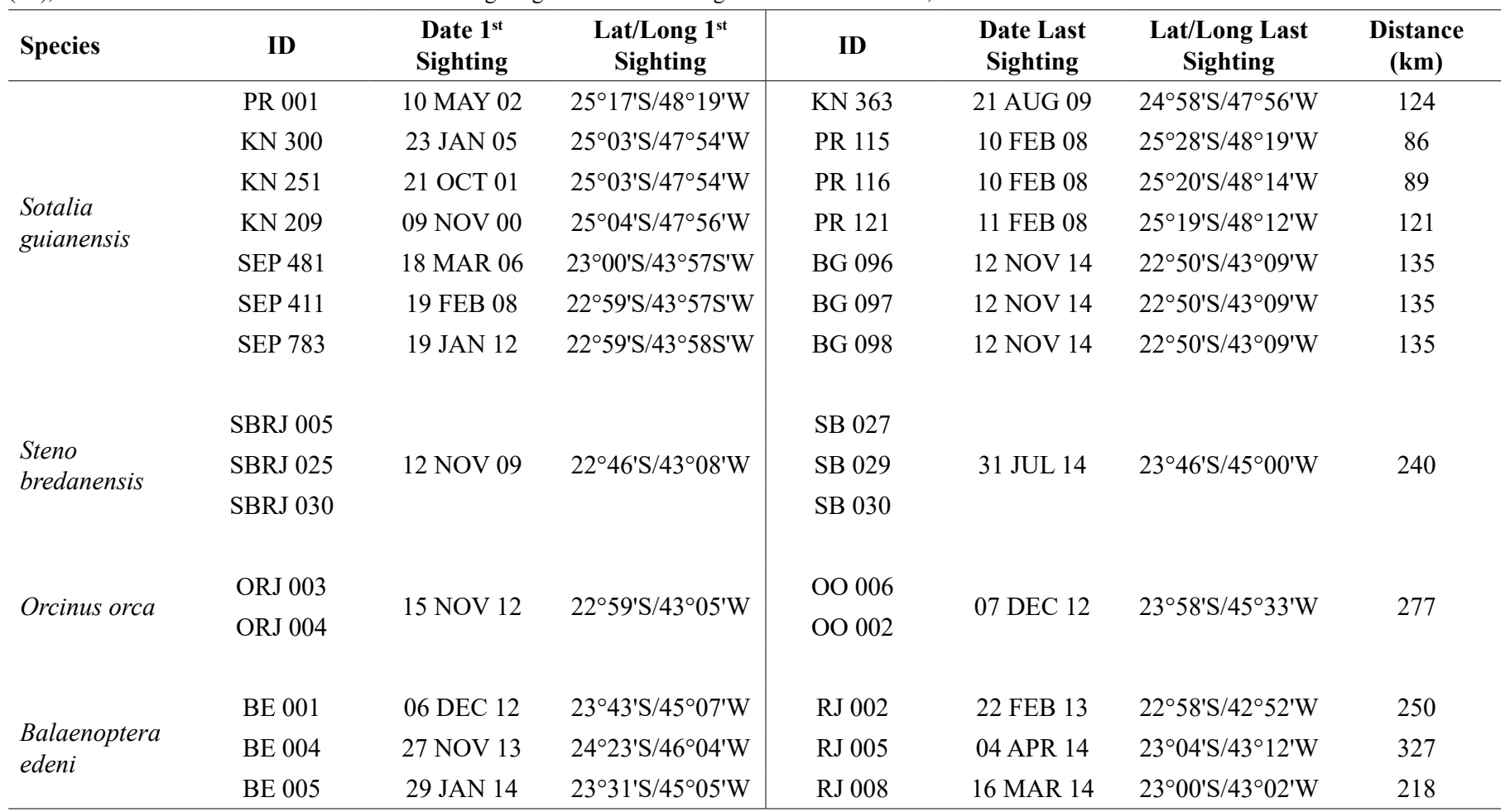

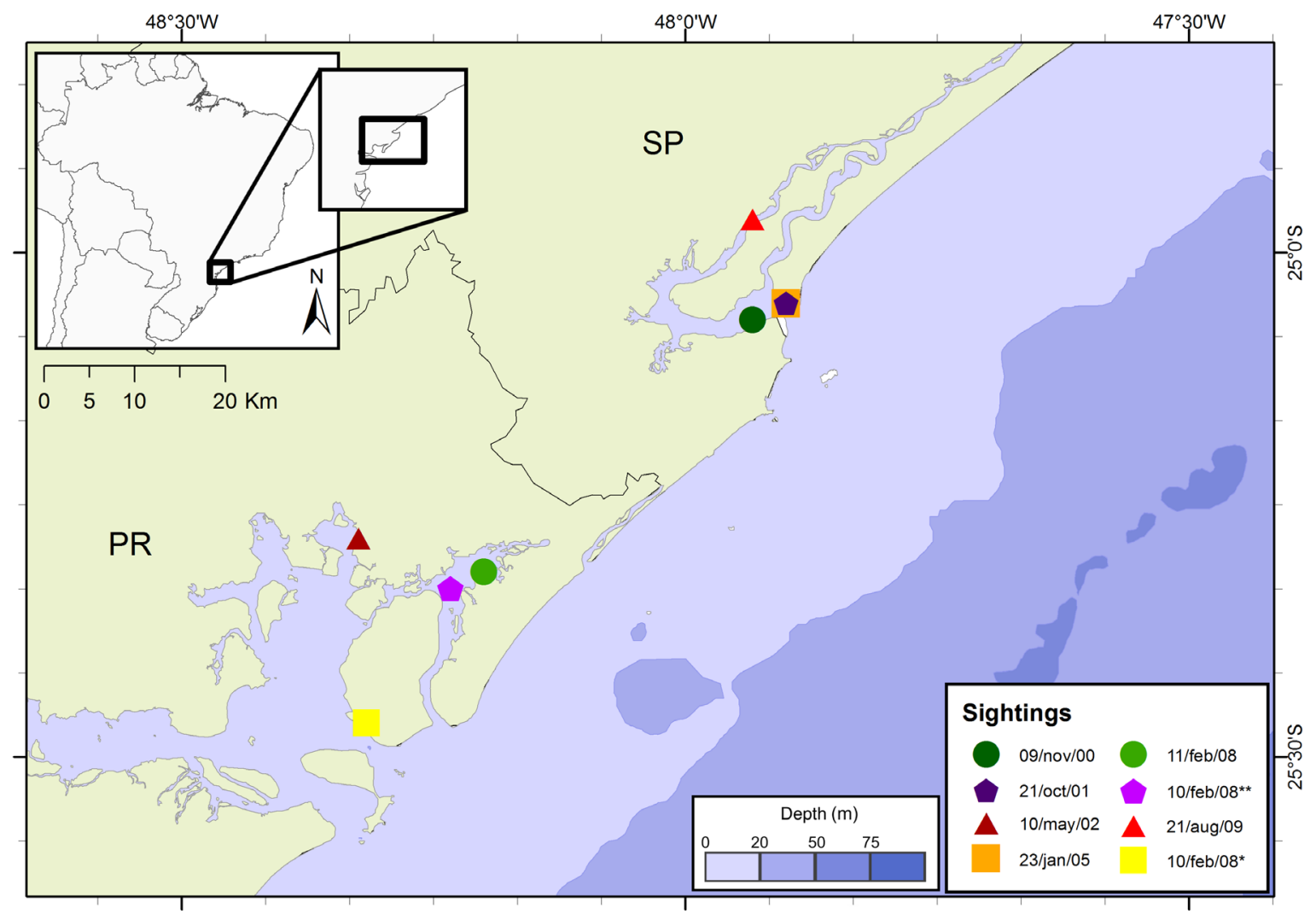

Figure 2. Map showing the estimated distances precluded by four Guiana dolphins switching between the Paranaguá Estuarine Complex in the state of Paraná (PR) and the Cananeia Estuary in the state of São Paulo (SP), southeastern Brazil, from November 2000 to August 2009. Each symbol represents one individual dolphin. The first sighting date is shown at the left column and the latest at the right one. Icons $(*)$ and $(* *)$ represent individuals sighted in the same date but in different groups. 


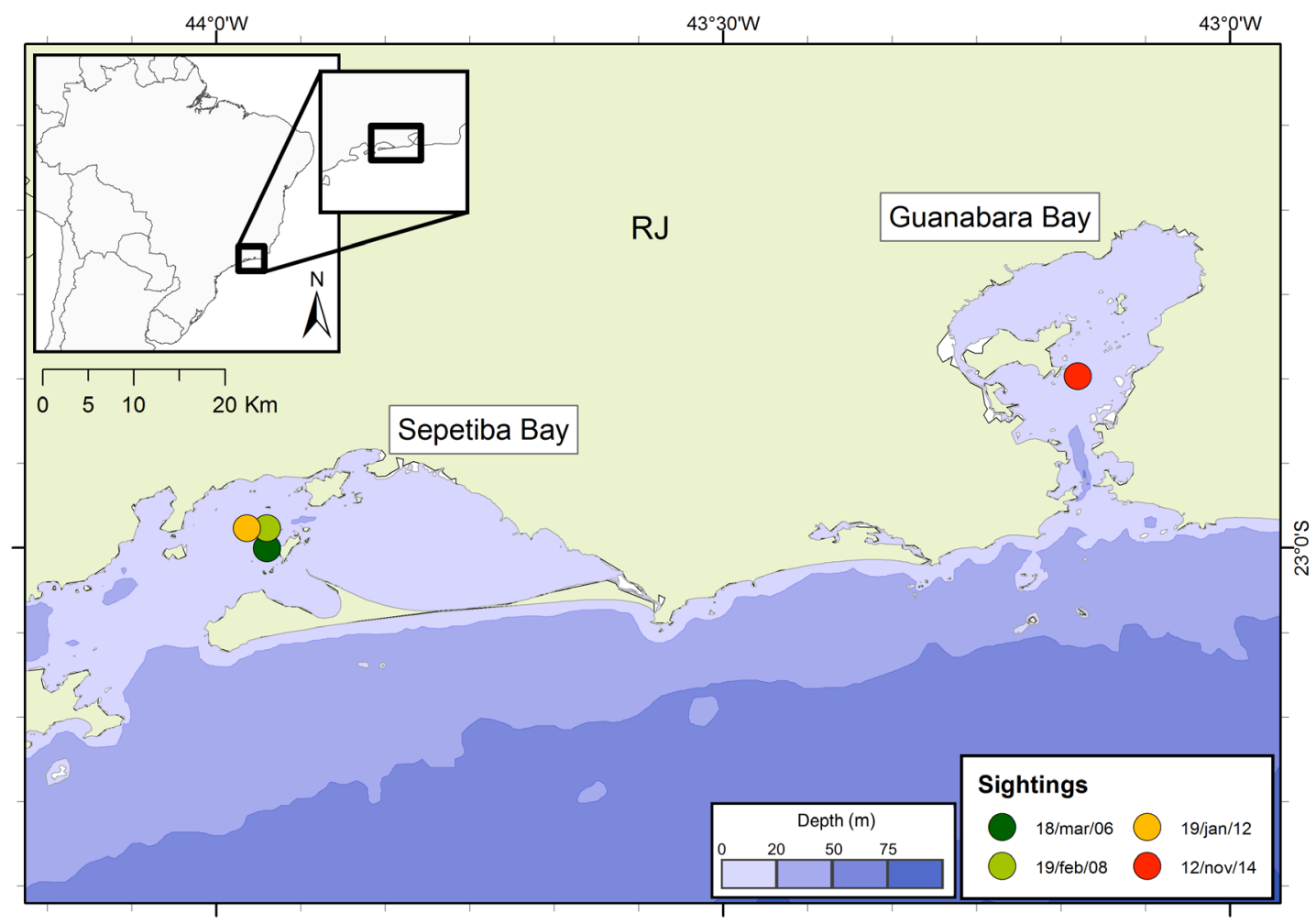

Figure 3. Map showing the estimated distances precluded by three Guiana dolphins switching between the Sepetiba bay and the Guanabara bay, both in the state of Rio de Janeiro (RJ), southeastern Brazil. The first sightings of each cataloged individual occurred in Sepetiba bay between March 2006 and January 2012, and the latest sighting of the three cataloged individuals in the same group occurred in November 2014.

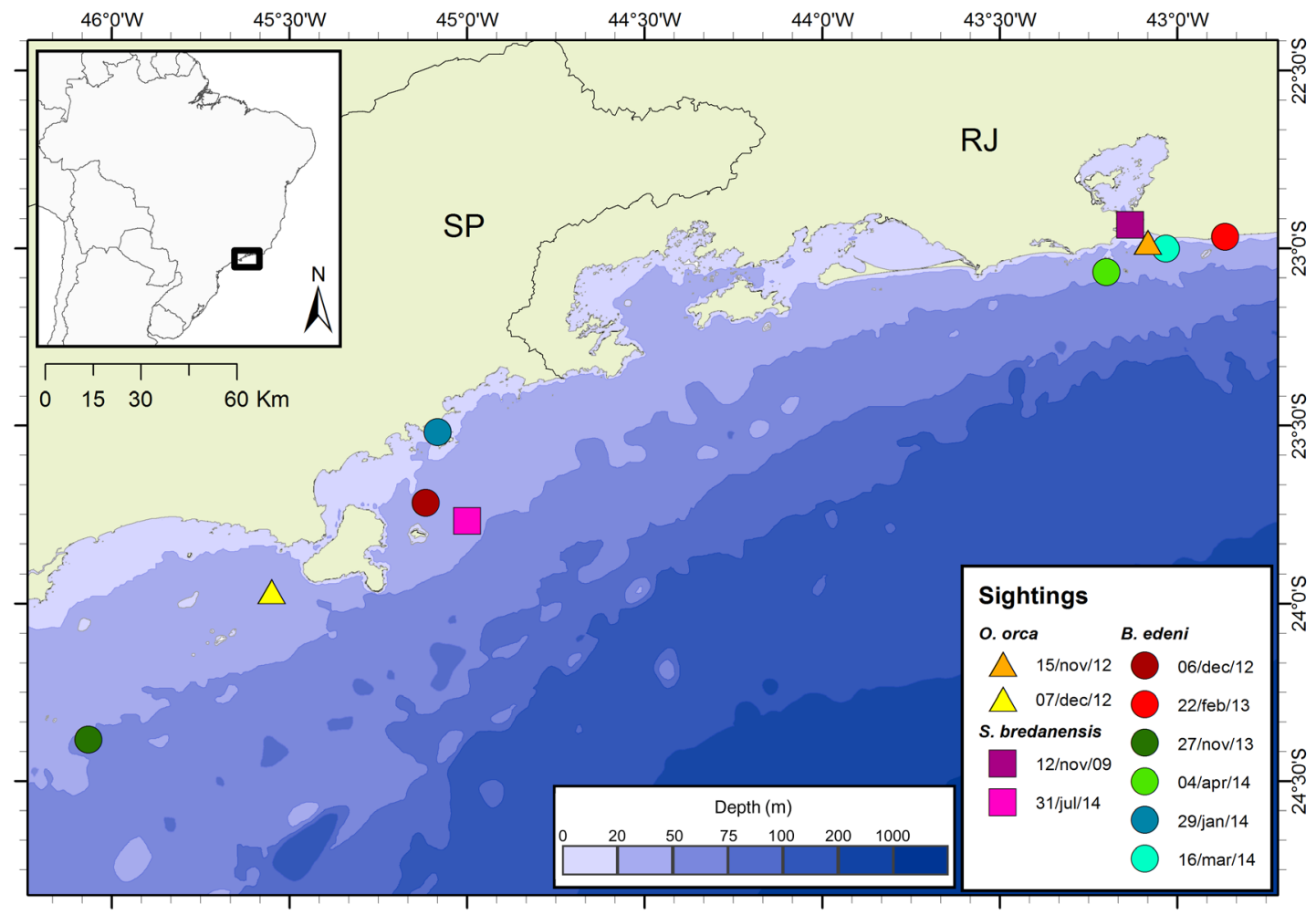

Figure 4. Map showing the estimated distances precluded by two identified rough-toothed dolphins in the same group in both sightings $(\Delta)$, two killer whales () also in the same group in both sightings, and three Bryde's whales never reported together (o) between 2009 and 2014 along the coast of the states of São Paulo (SP) and Rio de Janeiro (RJ), southeastern Brazil. 


\section{Orcas, Orcinus orca}

In a 27-day interval between November and December 2012, a group of 16 orcas travelled approximately $277 \mathrm{~km}$ in shallow coastal waters ranging from 20 to $30 \mathrm{~m}$ deep. Two cataloged individuals of the monitored group on the coast of Rio de Janeiro (OORJ 003 and 004) were re-sighted in São Paulo coastal waters (OO 002 and 006) (Table 2, Figure 4).

\section{Bryde's whales, Balaenoptera edeni}

In summer months between 2012 and 2014, three Bryde's whales sighted in waters ranging from 14 to $49 \mathrm{~m}$ deep, travelled distances between 218 and $327 \mathrm{~km}$ (Table 2, Figure 4). All movements occurred northwards from São Paulo to Rio de Janeiro coastal waters in late spring and summer. One adult individual (BE 001), sighted in December 2012 on the northern coast of São Paulo state, was re-sighted in the same summer season in February 2013 on the Rio de Janeiro state coast (RJ 002), travelling an estimated distance of $250 \mathrm{~km}$ after the first sighting. This adult individual was also re-sighted in February 2014 close to the same spot on the coast of Rio de Janeiro. The longest travelled distance was reported for the adult individual BE 004 (=RJ 005), which covered around $327 \mathrm{~km}$ between November 2013 and February 2014. Another re-sighting on 04 April 2014 was reported at an intermediate location almost at the same place. The last of the re-sighted individuals was an adult female followed by a young calf, seen in January 2014 on the northern coast of São Paulo state (BE 005), both re-sighted on three occasions from February to March 2014 on the coast of Rio de Janeiro state (RJ 008), after travelling ca. $218 \mathrm{~km}$ in 28 days.

\section{Discussion}

\section{Photo-identification technique and gathered results}

To evaluate cetacean movements in coastal waters of southeast Brazil, the authors relied on photo-identification. Although it seems to be cheaper when compared to the use of telemetry to gather information on individual movements, the cost involved in regular cruises conducted in time and space should be considered if the aim is to conduct longer-term studies. The time spent organizing and examining photographs, updating catalogs and looking for matches after seasons of field campaigns is considerably higher when compared, for instance, to analyzing satellite tagging location data (see Hammond et al. 1990, Hussey et al. 2015). However, photoidentification provides data on movements over a longer window of time when compared to tagging, and allows investigators to gather additional information on social organization, population abundance, calving intervals, etc. (see Hammond et al. 1990). One of the drawbacks of photo-identification is because it is not always guaranteed that all individuals in a group are precisely photographed, which adds to bias on results imposed by the selection and manipulation of images (Urian et al. 2015). Even with several drawbacks, photo-identification is the modus operandi to investigate cetaceans in their element in developing countries. However, it is not always guaranteed that research groups will be able to gather financial support to invest in longitudinal studies in those countries. This is the main reason why research efforts are usually unevenly distributed in time and space, as shown in this study. Notwithstanding, the results presented here are highly valuable based on the persistence of a few cetacean research groups working in a long stretch of coastal waters $(c a .700 \mathrm{~km})$ in Latin America over the past 20 years.

To date, the presented data and results are the outcome of the longest-term and largest-range photo-identification cetacean multispecies survey along the coast of Brazil. The authors analyzed 278,000 photographs to identify and follow 1,315 Guiana dolphins: possibly the largest numbers throughout the whole distribution of this shy and relatively small cetacean species. Movements of individuals belonging to four poorly known cetacean species in coastal waters of the SAO were detected, providing important clues to how they use the area. Added to the observations of Guiana dolphins, the analysis of 43,765 photographs helped to identify 578 individuals of 11 cetacean species, including rough-toothed dolphins, orcas and Bryde's whales, which were the other targets of the present study. Considering the whole study, authors analyzed 333,919 photographs to identify a total of 1,893 individuals.

\section{Guiana dolphins, Sotalia guianensis}

Even though the Guiana dolphin is the most common cetacean species dwelling along the coast of Brazil, the knowledge on individual movements is restricted to several bays and estuaries. In the present study, not only were visits to coastal waters by dolphins considered resident to bays and estuaries observed, but also longer-range movements between protected sites. The observed switches of individuals using two of the surveyed estuarine basins (CE and PEC) possibly occurred through coastal waters, as Guiana dolphins have never been reported in the man-made inner connective waters between the two larger monitored estuarine sites. The same pattern of coastal water movement was observed for three individuals that switched between the two surveyed protected bays in Rio de Janeiro (SEP and GB). Longer travel distances ranged from 86 to $135 \mathrm{~km}$, when individuals left one surveyed estuary/bay and entered another, representing the longest reported travelled distances by Guiana dolphins to date.

This leads to whether these long-range movements observed for several Guiana dolphins should be considered dispersal, defined as a permanent displacement of an individual from one area to another (Stern 2009). The most striking difference between dispersal and foraging movements lies in spatiotemporal scales, where the latter is performed within a home range and several times per day (Jeltsch et al. 2013). Dispersal is closely related to the metapopulation conceptual framework, which is defined as "populations connected by the dispersal of several individuals between them" (Hanski \& Gaggiotti, 2004). Dispersal reduces the risk of population extinction and maintains genetic heterozygozy (Stern 2009), which, in turn, is important in changing environments facing anthropogenic influences and/or climate change. All the reported seven individuals that moved between two estuaries/ bays have, so far, made permanent switches. The observed dispersal movements are likely to be the first data leading to an understanding of Guiana dolphins in a metapopulation context, providing better understanding of their distribution and area utilization in part of their geographic range.

\section{Rough-toothed dolphins, Steno bredanensis}

In the present study, a longer-range movement $(270 \mathrm{~km})$ on a larger time scale (3 years) was observed, showing that researchers chose reliable natural marks to catalog and follow individuals in time and 
space. Both sightings and re-sightings occurred in shallow depths (16 to $52.7 \mathrm{~m}$ ), reinforcing the use of shallower waters by $S$. bredanensis in southeastern Brazil. The three monitored individuals were seen in the same group on three occasions in five years, interesting evidence of close associations among them. The first support for strong bonds among individually marked rough-toothed dolphins was found in a survey conducted around Utila Island, Honduras (Kuczaj \& Yeater, 2007). In that study, a total of 12 individuals monitored through photo-identification showed strong site fidelity to local waters, as well as high association indices among themselves. Rough-toothed dolphins have been sighted in all seasons in the surveyed area. They may use a wider area, ranging from coastal to neritic waters, to cope with their biological and ecological requirements to survive. The movement of two rough-toothed dolphins of around $480 \mathrm{~km}$ was observed in Hawaii using photo-identification (Baird et al. 2008), showing clues that these dolphins are likely to have large home ranges.

\section{Orcas, Orcinus orca}

In this study, in a 27-day interval, a group of 16 orcas travelled around $277 \mathrm{~km}$ after sightings in shallow coastal waters $(20$ to $30 \mathrm{~m})$. To date, this is the only available information on movement of a group of orcas along the Brazilian coast. Orcas are social mammals and usually form social units containing a few to 20 or more individuals (Ford 2009). Thus, information on movements should be properly associated with these social units when the aim is to evaluate the importance of these movements to specific populations/stocks. Caution should thus be taken when considering the movement of $c a$. $600 \mathrm{~km}$ by a lone individual male reported in southeast Brazil (Santos \& Netto, 2005, Lodi \& Farias-Junior 2011), where it was witnessed killing and feeding on a La Plata dolphin (Santos \& Da Silva 2009). The feeding habits of orcas usually drive the range of their movement patterns, with fish specialists generally showing relatively shorter ranges when compared to mammal-eating orcas (Bigg et al. 1990, Baird \& Dill 1995, Ford \& Ellis 1999). The available data on feeding items, identified from both washed ashore individuals and live individuals, witnessed foraging and feeding activities along the Brazilian southern/southeastern coast to include cephalopod, fish (e.g., stingrays, weakfish, tuna and swordfish) and cetacean species (see a review in Santos \& Netto, 2005). A more detailed evaluation on the feeding habits of orcas, based on the use of additional tools such as stable isotopes and fatty acids, may possibly drive the investigators to the description of the existence of different social units/stocks in the coast of Brazil. Although orcas were witnessed attacking and killing Bryde's whales elsewhere (Silber et al. 1990, Alava et al. 2013), and both species have been commonly found in late spring and summer in the surveyed waters, this kind of interaction was still not reported in the studied area.

\section{Bryde's whales, Balaenoptera edeni}

Three adult Bryde's whales travelled distances ranging from 218 to $327 \mathrm{~km}$ in a two-year period, sighted in shallow coastal waters from 14 to $49 \mathrm{~m}$. These are the largest known ranges reported for $B$. edeni in the SAO. A previous investigation witnessed shorter-range movements of three individually marked Bryde's whales over a maximum distance of $126 \mathrm{~km}$ along the coast of Rio de Janeiro (Figueiredo et al. 2014). In all three sightings reported here, individuals were first sighted on the São
Paulo state coast at the end of spring and early summer, then moved northwards to the coast of Rio de Janeiro where they were sighted from mid to the end of summer. The considerably small sample size drives us to avoid assessing seasonal patterns. A general pattern of migration towards the Equator in winter and to higher latitudes in summer was described elsewhere for other ocean basins (see Kato \& Perrin 2009). Their destination in colder months in southeast Brazil remains a mystery. However, the influence of a cold and highly productive water mass, known as the South Atlantic Central Water (Sverdrup et al. 1942, Castro et al. 2006), may be responsible for the aggregation of their food supply in southeast Brazil in late spring and summer months, which is likely to represent the main trigger for their seasonal higher sighting rates.

\section{Final outcomes}

In conclusion, with the support of photo-identification, the first insights on long-range movements of four cetacean species were described for a poorly known area of the SAO. The reported observations regarding 15 individuals of four species represent important insights on cetacean movements in southeast Brazil. So far, these are the longest-range movement estimates reported for $S$. guianensis, $S$. bredanensis, $O$. orca and B. edeni in the surveyed area. Except for Guiana dolphins in a few estuarine basins, for the three other cetacean species presented here, there is no available information on their abundance, seasonality of local coastal water utilization, or even data on life history traits in the SAO. As a consequence, the clues presented here begin to pave the next steps to better understand the dynamics related to cetacean movements in local coastal waters, as well as to better investigate further aspects of their biology and ecology. Other cetacean species have also been found in the surveyed area (see Santos et al. 2017). Their shorter-range movements are under investigation and should provide clues on the role they play in spatiotemporal cetacean biodiversity patterns.

For the four cetacean species studied here, two are categorized as "data deficient" by the IUCN (O. orca and B. edeni), one as "near threatened" (Sotalia guianensis) and, although still poorly known, $S$. bredanensis is listed in the category "least concern" (see Hammond et al. 2012, Reilly et al. 2012, Taylor et al. 2013, Secchi et al., 2018). That makes absolutely clear that studies on the dynamics of cetacean movements are still in need in most ocean basins.

\section{Acknowledgments}

The Yatch Club Ilhabela (YCI) kindly provided a safe and comfortable port when surveys were conducted along the northern coast of São Paulo state. We thank the Faculdade de Oceanografia (UERJ), Iate Clube Jardim Guanabara and the administration of Guapimirim Environmental Protection Area for their logistical support. Linda Waters reviewed the final version of this manuscript to adjust grammar and English flow.

\section{Financial support}

The Guiana dolphin longitudinal study in the Cananéia Estuary was funded by the Cetacean Society International (CSI), the Whale and Dolphin Conservation Society, the Earthwatch Institute (EWI) and the 
Fundação de Amparo à Pesquisa do Estado de São Paulo (FAPESP; Process 01/05128-8; 2005/59439-5; 2005/54149-9). In the Paranaguá Estuarine Complex, the financial support came from the CSI, the EWI and FAPESP (Process 2005/59439-5; 2005/54149-9). Júlia Emi de Faria Oshima received grants from Programa de Recursos Humanos da ANP para o setor de petróleo e gás - PRH 05-ANP/MCT/FINEP (Process 48610002667/99-16) and grants and a fellowship from the Fundação de Amparo à Pesquisa do Estado de São Paulo (FAPESP) (Process 2008/56543-4). Coastal surveys along São Paulo state were funded by FAPESP (Process 2011/51543-9). The survey at the Parque Estadual Marinho da Laje de Santos conducted between 2013 and 2015 was funded through an environmental license process issued by the Instituto Brasileiro do Meio Ambiente e dos Recursos Naturais Renováveis (IBAMA) to regulate the natural gas production and outflow system from the Campo de Merluza at Santos Basin under Petrobras (Process 02022.010930/2002-19). The Guiana dolphin longitudinal study in Sepetiba Bay was funded by TELBRAX, MBR.SA, VALE and sponsored by PETROBRAS through Petrobras Socioambiental. We are grateful to the MAQUA team for field assistance and insightful advice. Rio de Janeiro State Government Research Agency (FAPERJ) and Cetacean Society International have supported research developed by MAQUA in Guanabara Bay. AFA and JL-B have research grant from CNPq (PQ-1D), FAPERJ (JCNE) and UERJ (Prociência).

\section{Author Contributions}

Marcos C. de O. Santos: Substantial contribution in the concept and design of the study. Contribution to data collection. Contribution to data analysis and interpretation. Contribution to manuscript preparation. Contribution to critical revision, adding intellectual contente.

José Laílson-Brito: Contribution to data collection. Contribution to data analysis and interpretation. Contribution to manuscript preparation. Contribution to critical revision, adding intellectual contente.

Leonardo Flach: Contribution to data collection. Contribution to data analysis and interpretation. Contribution to manuscript preparation. Contribution to critical revision, adding intellectual contente.

Júlia E. F. Oshima: Contribution to data collection. Contribution to data analysis and interpretation. Contribution to manuscript preparation. Contribution to critical revision, adding intellectual contente.

Giovanna C. Figueiredo: Contribution to data collection. Contribution to data analysis and interpretation. Contribution to manuscript preparation. Contribution to critical revision, adding intellectual contente.

Rafael R. Carvalho: Contribution to data collection. Contribution to data analysis and interpretation. Contribution to manuscript preparation. Contribution to critical revision, adding intellectual contente.

Elisa S. Ventura: Contribution to data collection. Contribution to data analysis and interpretation. Contribution to manuscript preparation. Contribution to critical revision, adding intellectual contente.

Julia M. B. Molina: Contribution to data collection. Contribution to data analysis and interpretation. Contribution to manuscript preparation. Contribution to critical revision, adding intellectual contente.

Alexandre F. Azevedo: Contribution to data collection. Contribution to data analysis and interpretation. Contribution to manuscript preparation. Contribution to critical revision, adding intellectual contente.

\section{Conflict of Interest}

The authors declare that they have no conflict of interest related to the publication of this manuscript.

\section{References}

ALAVA J.J., SMITH K.J., O’HERN J., ALARCÓN D., MERLEN G. \& DENKINGER J. 2013. Observations of killer whale (Orcinus orca) attacks on Bryde's Whales (Balaenoptera edeni) in the Galápagos islands. Aquatic Mammals 39, 196-201.

ANDRIOLO A., DA ROCHA J.M., ZERBINI A.N., SIMÕES-LOPES P.C., MORENO I.B., LUCENA A., DANILEWICZ D. \& BASSOI M. 2010. Distribution and relative abundance of large whales in a former whaling ground off eastern South America. Zoology 27, 741-750.

AZEVEDO, A.F., LAILSON-BRITO, J.JR., CUNHA, H.A. \& SLUYS, M.V. 2004. A note on site fidelity of marine tucuxis (Sotalia fluviatilis) in Guanabara Bay, southeastern Brazil. Journal of Cetacean Research and Management 6, 265-268.

AZEVEDO A.F., OLIVEIRA A.M., VIANA S.C. \& VAN SLUYS M. 2007. Habitat use by marine tucuxis (Sotalia guianensis) (Cetacea: Delphinidae) in Guanabara Bay, south-eastern Brazil. Journal of the Marine Biological Association 87, 201-205.

BAIRD R.W. \& DILL L.M. 1995. Occurrence and behaviour of transient killer whales: seasonal and pod-specific variability, foraging behaviour, and prey handling. Canadian Journal of Zoology 73, 1300-1311.

BAIRD R.W., WEBSTER D.L., MAHAFFY S.D., MCSWEENEY D.J., SCHORR G.S. \& LIGON A.D. 2008. Site fidelity and association patterns in a deep-water dolphin: rough-toothed dolphins (Steno bredanensis) in the Hawaiian Archipelago. Marine Mammal Science 24, 535-553.

BIGG M.A., OLESIUK P.F., ELLIS G.M., FORD J.K.B. \& BALCOMB K. C. 1990. Social organization and genealogy of resident killer whales (Orcinus orca) in the coastal waters of British Columbia and Washington State. Report of the International Whaling Commission 12, 383-405.

CASTRO B.M., LORENZZETTI J.A., DA SILVEIRA I.C.A. \& MIRANDA L.B. 2006. Estrutura termohalina e circulação na região entre o Cabo de São Tomé (RJ) e o Chuí (RS). In C.L.D.B. Rossi-Wongtschowski and L.S. Madureira (eds.), O ambiente oceanográfico da plataforma continental $e$ do talude na região sudeste-sul do Brasil. Editora da Universidade de São Paulo, SP, pp. 11-20.

COMMITTEE ON TAXONOMY. 2018. List of marine mammal species and subspecies. Society for Marine Mammalogy. www.marinemammalscience. org (consulted on 25 May 2018).

COSTA, A.F., SICILIANO, S., EMIN-LIMA, R., MARTINS, B.M.L., SOUSA. M.E.M., GIARRIZZO, T. \& SILVA-JUNIOR, J.S. 2017. Stranding survey as a framework to investigate rare cetacean records of the north and north-eastern Brazilian coasts. ZooKeys 688, 111-134.

CYPRIANO-SOUZA, A.L., MEIRELLES, A.C.O., CARVALHO, V.L. \& BONATTO, S.L. 2017. Rare or cryptic? The first report of an Omura's whale (Balaenoptera omurai) in the South Atlantic Ocean. Marine Mammal Science 33, 80-95.

DAHLHEIM M.E., SCHULMAN-JANIGER A., BLACK N., TERNULLO R. ELLIFRIT D. \& BALCOMB K.C. 2008. Eastern temperate North Pacific offshore killer whales (Orcinus orca): occurrence, movements, and insights into feeding ecology. Marine Mammal Science 24, 719-729.

DA SILVA, V.M.F., FETTUCCIA, D., RODRIGUES, E.S., EDWARDS, H., MORENO, I.B., MOURA, J.F., WEDEKIN, L.L., BAZZALO, M., EMINLIMA, N.R., CARMO, N.A.S., SICILIANO, S. \& UTRERAS, V.B. 2010 Report on the working group on distribution, habitat characteristics and preferences, and group size. Latin American Journal of Aquatic Mammals 8, 31-38

DIAS L.A., HERZING D. \& FLACH L. 2009. Aggregations of Guiana dolphins (Sotalia guianensis) in Sepetiba bay, Rio de Janeiro, southeast Brazil distribution patterns. Journal of the Marine Biological Association 89, 967-973. 
DI TULLIO, J.C., GANDRA, T., ZERBINI, A.N. \& SECCHI, E.R. 2016. Diversity and distribution patterns of cetaceans in the subtropical Southwestern Atlantic outer continental shelf and slope. Plos One 11, p. e0155841.

DURBAN J.W. \& PITMAN R. L. 2012. Antarctic killer whales make rapid, round-trip movements to subtropical waters: evidence for physiological maintenance migrations? Biology Letters 8, 274-277.

FEARNBACH H., DURBAN J.W., ELLIFRIT D.K., WAITE J.M., MATKIN C.O., LUNSFORD C.R., PETERSON M.J., BARLOW J. \& WADE P. R. 2014. Spatial and social connectivity of fish-eating "resident" killer whales (Orcinus orca) in the northern North Pacific. Marine Biology 161, 459-472.

FIGUEIREDO L.D., TARDIN R.H., LODI L., MACIEL I.S., ALVES M.A.S. \& SIMÃO S. M. 2014. Site fidelity of Bryde's whales (Balaenoptera edeni) in Cabo Frio region, southeastern Brazil, through photoidentification technique. Brazilian Journal of Aquatic Science and Technology 18, 59-64.

FLACH L., FLACH P.A. \& CHIARELLO, A.G. 2008. Aspects of behavioral ecology of Sotalia guianensis in Sepetiba bay, southeast Brazil. Marine Mammal Science 24, 503-515.

FLORES, P.A.C. 1999. Preliminary results of a photoidentification study of the marine tucuxi Sotalia fluviatilis in southern Brazil. Marine Mammal Science 15, 840-847.

FLORES P.A.C. \& BAZZALO M. 2004. Home ranges and movement patterns of the marine tucuxi dolphin Sotalia fluviatilis, in Baía Norte, Southern Brazil. Latin American Journal of Aquatic Mammals 3, 37-52.

FORD J.K.B. 2009. Killer whale Orcinus orca. In W.F.Perrin, B., Würsig, and J.G. M. Thewissen, (eds.), Encyclopedia of marine mammals. Academic Press, San Diego, CA, pp. 650-657.

FORD J.K.B. \& ELLIS G.M. (Eds.) 1999. Transients: mammal-hunting orcas of British Columbia, Washington, and Southeastern Alaska. UBC Press and University of Washington Press, Vancouver, BC and Seattle, WA.

FRUET, P.F., SECCHI, E.R., DI TULLIO, J.C. \& KINAS, P.G. 2011. Abundance estimation of bottlenose dolphins, Tursiops truncatus (Cetacea, Delphinidae), inhabiting the Patos Lagoon estuary, southern Brazil: implications for conservation. Zoologia 28, 23-30.

FRUET, P.F., GENOVES, R.C., MOLLER, L.M., BOTTA, S. \& SECCHI, E.R. 2015. Using mark-recapture and stranding data to estimate reproductive traits in female bottlenose dolphins (Tursiops truncatus) of the Southwestern Atlantic Ocean. Marine Biology 162, 661-673.

GREIG, A.B., SECCHI, E.R., ZERBINI, A.N. \& DALLA ROSA, L. 2001. Stranding events of southern right whales, Eubalaena australis, in southern Brazil. Journal of Cetacean Research and Management Special Issue 2, 157-160.

HAMMOND P.S., MIZROCH S.A. \& DONOVAN G.P. (Eds.) 1990. Individual recognition of cetaceans: use of photo-identification and other techniques to estimate population parameters. Report of the International Whaling Commission, special issue 12. Cambridge, UK.

HAMMOND P.S., BEARZI G., BJØRGE A., FORNEY K.A., KARKZMARSKI L., KASUYA T., PERRIN W.F., SCOTT M.D., WANG J.Y., WELLS R.S. \& WILSON B. 2012. Steno bredanensis. The IUCN Red List of Threatened Species. Version 2015.2. <www.iucnredlist.org>. Downloaded on 28 May 2018.

HANSKI I. \& GAGGIOTTI, O.E. 2004. Metapopulation biology: past, present and future. In I. Hanski, and O.E. Gaggiotti (eds.) Ecology, genetics and evolution of metapopulations. Elsevier Academic Press, pp. 3-22.

HEYNING J.E. \& DAHLHEIM M.E. 1988. Orcinus orca. Mammalian Species $304,1-9$.

HUSSEY N.E., KESSEL S.T., AARESTRUP K., COOKE S.J., COWLEY P.D., FISH A.T., HARCOURT R.G., HOLLAND K.N., IVERSON S.J., KOCIK J.F., FLEMMING J.E.M. \& WHORISKEY F.G. 2015. Aquatic animal telemetry: a panoramic window into the underwater world. Science 348. DOI $10.1126 /$ science. 1255642 .
JELTSCH F., BONTE D., PE'ER G., REINEKING B., LEIMGRUBER P., BALKENHOL N., SCHÖDER B., BUCHMANN C.M., MUELLER T., BLAUM N., ZURELL D., BÖHNING-GAESE K., WIEGAND T., ECCARD J.A., HOFER H., REEG J., EGGERS U. \& BAUER S. 2013. Integrating movement ecology with biodiversity research - exploring new avenues to address spatiotemporal biodiversity dynamics. Movement Ecology 1,1-13.

KATO H. \& PERRIN W.F. 2009. Bryde's whales Balaenoptera edeni/brydei. In W.F. Perrin, B., Würsig, and J.G.M. Thewissen, (eds.), Encyclopedia of marine mammals. Academic Press, San Diego, CA, pp. 158-163.

KJERFVE B., RIBEIRO C.H.A., DIAS G.T.M., FILIPPO A.M. \& QUARESMA V.S. 1997. Oceanographic characteristics of an impacted coastal bay: Baía de Guanabara, Rio de Janeiro, Brazil. Continental Shelf Research 17, 1609-1643.

KUCZAJ S.A. \& YEATER D.B. 2007. Observations of rough-toothed dolphins (Steno bredanensis) off the coast of Utila, Honduras. Journal of the Marine Biological Association 87, 141-148.

LODI L. 1992. Epimeletic behavior of free-ranging rough-toothed dolphins, Steno bredanensis, from Brazil. Marine Mammal Science 8, 284-287.

LODI L. \& HETZEL, B. 1999. Rough-toothed dolphin, Steno bredanensis, feeding behaviors in Ilha Grande Bay, Brazil. Biociencias 7, 29-42.

LODI L. \& FARIAS-JUNIOR S. 2011. Movements of a solitary adult male killer whale, Orcinus orca (Cetacea, Delphinidae), along the coast of south-eastern Brazil. Panamerican Journal of Aquatic Sciences 6, 325-328.

LODI L., OLIVEIRA R.H.T., FIGUEIREDO L.D. \& SIMÃO S. M. 2012. Movements of the rough-toothed dolphin (Steno bredanensis) in Rio de Janeiro state, south-eastern Brazil. Marine Biodiversity Records 5, e47 (4 pages), Published online.

MATTHEWS C.J.D., LUQUE S.P., PETERSEN S.D., ANDREWS R.D. \& FERGUSON S.H. 2011. Satellite tracking of a killer whale (Orcinus orca) in the eastern Canadian Arctic documents ice avoidance and rapid, longdistance movement into the North Atlantic. Polar Biology 34, 1091-1096.

MOURA J.F. \& SICILIANO S. 2012. Stranding pattern of Bryde's whales along the south-eastern coast of Brazil. Marine Biodiversity Records 5, e73 (7 pages), Published online.

NATHAN R., GETZ W.M., REVILLA E., HOLYOAK M., KADMON R., SALTZ D. \& SMOUSE P.E. 2008. A movement ecology paradigm for unifying organismal movement research. Proceedings of the National Academy of Sciences 105, 19052-19059.

NOERNBERG, M.A., LAUTERT L.F.C., ARAÚJO A.D., MARONE E., ANGELOTTI R., NETTO JR J.P.B. \& KRUG L.A. 2006. Remote sensing and GIS integration for modelling the Paranaguá estuarine complex-Brazil. Journal of Coastal Research 39, 1627-1631.

OSHIMA J.E.F., SANTOS M.C.O., BAZZALO M., FLORES, P.A.C. \& PUPIM F.N. 2010. Home ranges of Guiana dolphins (Sotalia guianensis) (Cetacea: Delphinidae) in the Cananéia estuary, Brazil. Journal of the Marine Biological Association 90, 1641-1647.

OSHIMA J.E.F. \& SANTOS, M.C.O. 2016. Guiana dolphin home range analysis based on 11 years of photo-identification research in a tropical estuary. Journal of Mammalogy 97, 599-610.

RAMOS, R.; SICILIANO, S.; BOROBIA, M.; ZERBINI, A.; PIZZORNO, J.L.; FRAGOSO, B.; BRITO JR, J.L.; AZEVEDO, A. DE F.; LOPES, P.C.S. \& SANTOS, M.C.O. 2001. A note on strandings and age of sperm whales (Physeter macrocephalus) on the Brazilian coast. Journal of Cetacean Research and Management 3, 321-327.

REILLY S.B., BANNISTER J.L., BEST P.B., BROWN M., BROWNELL JR R.L., BUTTERWORTH D.S., CLAPHAM P.J., COOKE J., DONOVAN G.P., URBÁN J., \& ZERBINI A.N. 2008. Balaenoptera edeni. The IUCN Red List of Threatened Species. Version 2015.2. <www.iucnredlist.org>. Downloaded on 28 May 2018.

SANTOS, M.C.O., ROSSO, S., SICILIANO, S., ZERBINI, A., ZAMPIROLLI, E., VICENTE, A.F.C. \& ALVARENGA, F. 2000. Behavioral observations on the marine tucuxi dolphin (Sotalia fluviatilis) in São Paulo estuarine waters, Southeastern Brazil. Aquatic Mammals 23, 260-267. 
SANTOS, M.C.O.; ACUÑA, L. \& ROSSO, S. 2001. Insights on site fidelity and calving intervals of the marine tucuxi dolphin (Sotalia fluviatilis) in south-eastern Brazil. Journal of the Marine Biological Association of the United Kingdom 81, 1049-1052

SANTOS M.C.O. \& NETTO D.F. 2005. Killer whale (Orcinus orca) predation on a franciscana dolphin (Pontoporia blainvillei) in Brazilian waters. Latin American Journal of Aquatic Mammals 4, 69-72.

SANTOS M.C.O. \& DA SILVA E. 2009. Records of a male killer whale (Orcinus Orca) off southeastern Brazil. Brazilian Journal of Oceanography 57, 65-68.

SANTOS M.C.O., SICILIANO S., VICENTE A.F.C., ALVARENGA F.S., ZAMPIROLLI E., SOUZA S.P. \& MARANHO A. 2010a. Cetacean records along São Paulo state coast, southeastern Brazil. Brazilian Journal of Oceanography 57, 123-142.

SANTOS M.C.O., OSHIMA J.E.F., PACÍFICO E.S. \& DA SILVA E. $2010 \mathrm{~b}$. Guiana dolphins, Sotalia guianensis (Cetacea: Delphinidae) sispin the Paranaguá estuarine complex: insights on the use of area based on the photo-identification technique. Zoology 27, 324-330.

SANTOS, M.C.O., FIGUEIREDO, G.C. \& VAN BRESSEM, M.F. 2017. Cetaceans using the marine protected area of "Parque Estadual Marinho da Laje de Santos", southeastern Brazil. Brazilian Journal of Oceanography $65,605-613$.

SECCHI, E.R., SANTOS, M.C. de O. \& REEVES, R.R. 2018. Sotalia guianensis. The IUCN Red List of Threatened Species 2018: e.T181359A50386256. http://dx.doi.org/10.2305/IUCN.UK.2018-2.RLTS.T181359A50386256. en. Downloaded on 23 February 2019.

SICILIANO, S. 1994. Review of small cetaceans and fishery interactions in coastal waters of Brazil. Reports of the International Whaling Commission $15,241-250$

SICILIANO S., LAÍLSON-BRITO J. \& AZEVEDO A.F. 1999. Seasonal occurrence of killer whales (Orcinus orca) in waters of Rio de Janeiro, Brazil. Zeitschrift Fur Saugetierkunde (Mammalian Biology) 64, 251-255.

SICILIANO S., SANTOS, M.C.O., VICENTE, A.F.C., ALVARENGA F.S., ZAMPIROLLI E., LAÍLSON-BRITO J., AZEVEDO A.F. \& PIZZORNO J.L. 2004. Strandings and feeding records of Bryde's whales (Balaenoptera edeni) in south-eastern Brazil. Journal of the Marine Biological Association $84,857-859$.

SILBER G.K., NEWCOMER M.W. \& PEREZ CORTES, M.H. 1990. Killer whales (Orcinus orca) attack and kill a Bryde's whale (Balaenoptera edeni). Canadian Journal of Zoology 68, 1603-1606.
SIMÕES-LOPES, P.C. \& FABIAN, M.E. 1999. Residence patterns and site fidelity in bottlenose dolphins, Tursiops truncatus (Montagu) (Cetacea, Delphinidae) off Southern Brazil. Revista Brasileira de Zoologia 16, 1017-1024.

SMA 1991. Macrozoneamento do complexo estuarino-lagunar de Iguape e Cananéia. Secretaria do Meio Ambiente (SMA), Programa Estadual de Gerenciamento Costeiro, São Paulo, SP, Brasil.

STERN S.J. 2009. Migration and movement patterns. In W.F. Perrin, B., Würsig, and J.G.M. Thewissen (eds.), Encyclopedia of marine mammals. Academic Press, San Diego, CA, pp. 726-730.

STEWMAN J., DEBURE K., HALE S. \& RUSSEL A. 2006. Interative 3-D pose correction and content-based image retrieval for dorsal fin recognition. In J. Stewman, K. Debure, S. Hale and A. Russel, A. (eds.). Image analysis and recognition: lecture notes in computer science. Springer-Verlag, pp. 648-660.

SVERDRUP H.U., JONHSON M.W. \& FLEMING R.H. (Eds.) 1942. The Oceans: their physics, chemistry, and general biology. New York, Prentice Hall.

TAYLOR B.L., BAIRD R., BARLOW J., DAWSON S.M., FORD J., MEAD J.G., NOTARBARTOLO DI SCIARA G., WADE P. \& PITMAN R. L. 2013. Orcinus orca. The IUCN Red List of Threatened Species. Version 2015.2. $<$ www.iucnredlist.org $>$. Downloaded on 18 May 2018.

URIAN K., GORGONE, A., READ A., BALMER, B., WELLS, R.S., BERGGREN, P., DURBAN, J., EGUCHI, T., RAYMENT W. \& HAMMOND P. S. 2015. Recommendations for photo-identification methods used in capture-recapture models with cetaceans. Marine Mammal Science $31,298-321$

WEST K.L., MEAD J.G. \& WHITE W. 2011. Steno bredanensis (Cetacea: Delphinidae). Mammalian Species 43, 177-189.

WURSIG, B. \& JEFFERSON, T.A. 1990. Methodology of photo-identification for small cetaceans. In P.S. Hammond, S.A. Mizroch and G. P. Donovan (eds.), Individual recognition of cetaceans: use of photo-identification and other techniques to estimate population parameters. International Whaling Commission, Special Issue, no. 12, pp. 43-52.

ZERBINI, A.N., SECCHI, E.R., SICILIANO, S. \& SIMÕES-LOPES, P.C. 1997. A review on the occurrence and distribution of whales of the genus Balaenoptera along the Brazilian coast. Reports of the International Whaling Commission 47, 407-417. 